\section{Performance of lamp glass waste powder (LGWP) as supplementary cementitious material (SCM) - viscosity and electrical conductivity}

\author{
PATRICIA KARA - Lecturer, RTU, Riga, Latvia - patricija.kara@rtu.Iv \\ Érkezett: 2015. 02. 10. - Received: 10. 02. 2015. " http://dx.doi.org/10.14382/epitoanyag-jsbcm.2015.3
}

Patricia KARA

Civil engineer (MSc), Lecturer at Department of Building Materials and Products in Institute of Materials and Structures at Riga Technical University (Latvia). RILEM Affiliate Member of Technical committees: TC AAA, TC RSC, TC SIF, TC 225-SAP and TC 219-ACS. Member of ACI Italy Chapter. Member of Latvian Concrete Association. Main research area: concrete technology, waste glass recycling, recycling of industrial wastes and by-products in concrete, environmental management, eco-construction materials

\begin{abstract}
Rheological behaviour of fresh mortars is a key characteristic since it determines workability, compaction and segregation properties of the material and greatly influences the final characteristics of the hardened product. Substituting Portland cement with pulverised lamp glass waste (incandescent light bulb borosilicate glass waste cullet and fluorescent lamp tube glass waste cullet) in concrete has a significant effect on its workability and strength. Present study evaluates the effectiveness of lamp glass waste cullet at a level of $30 \%$ as cement component in mortar and determines the grinding time for optimal physical and mechanical properties of mortars. Viscosity, electrical conductivity, ultrasound pulse velocity and compressive strength of such cement mortars were determined. The results showed that the finer the incandescent light bulb borosilicate glass waste cullet powder particles were, the lower were the viscosity, ultrasound pulse velocity and electrical conductivity. However, the finer the fluorescent lamp tube glass waste cullet powder particles were, the higher were the viscosity and electrical conductivity. An increase in compressive strength was observed for cement mortars with incandescent light bulb borosilicate glass waste cullet powder.

Keywords: recycling, viscosity, electrical conductivity, lamp glass waste powder, borosilicate glass waste cullet, fineness
\end{abstract}

\section{Introduction}

The production of Portland cement leads to the release of significant amount of $\mathrm{CO}_{2}$ and one of the biggest threats to the sustainability of cement industry is the diminishing stock of limestone available in some geographical regions. As limestone becomes a limited resource, employment and construction activity associated with cement-based materials are affected; therefore, those involved with these industries must develop new techniques for creating cementbased construction materials with reduced use of limestone. Indeed, clinker can be blended with pozzolanic materials, such as coal or bio-mass fly ash, slag, silica fume, or other pozzolanic materials such as finely ground waste glass [1]. In recent years, research has shown that increasing the surface area to volume ratio of glass will reduce the effects of alkalisilica reaction (ASR) i.e. practically by using glass milled to finer particles [2]. Ground glass powders exhibit very good pozzolanic reactivity and can be used as cement replacement; as expected, their pozzolanic reactivity increases with fineness [3]. Since increasing amounts of hazardous materials need to be disposed in a safe and economical way, the wastes may be considered as a real opportunity to produce clean secondary raw materials, thereby reducing costs and conserving resources [4]. Glass waste corresponds to several types of post-consumer products and can be completely recycled. Since most of the glass waste is made with soda-lime material, its melting and working temperatures are relatively low, which makes it easy to reprocess. But in spite of the recycling advantage, a large amount of glass waste is still discarded in landfills or simply thrown into the environment, including fluorescent lamps [5]. Fluorescent lamps are used widely all over the world due to their long life and energy saving capability. Fluorescent and high intensity discharge lamps contain mercury, lead, and other components of environmental concern [6]. According to the data from $\mathrm{LaDeCe}$ - the only lamp recycling centre in the Baltic States located in Liepaja (Latvia) -, the accumulated amount of lamp glass waste in the period from 2004 to 2012 is 1,800 tonnes from which 500 tonnes were exported outside of Latvia [7].

\section{Rheological aspects of the application of lamp glass waste powder}

The major part of research in the area of application of waste glass powder in concrete is focused on the mechanical and durability aspects, e.g. compressive and flexural strengths, ASR, shrinkage and cracking in recent years. Workability tests were performed mostly by flow table and slump tests and it was noticed that: a) waste glass (coloured soda bottles) addition increased workability due to the fact that waste glass does not absorb water and that the water layer over the surface of waste glass is thinner [8]; b) a higher dosage of ground sodiumcalcium waste glass required a higher water dosage to reach the same flow value as with the reference mortar [2]; c) the use of finely milled waste glass obtained from fluorescent lamps in concrete mixtures had an adverse effect on workability [9]; d) workability of concrete mixture containing borosilicate lamp glass $\left(\mathrm{B}_{2} \mathrm{O}_{3}: 16.6 \%\right)$ was satisfactory, but the mixture had a tacky consistency [10] also termed as more adhesive consistency 
[11] compared to a conventional concrete mixture reference; with the improved mixture workability resulting in more homogenous mixtures without any segregation. In the present study workability behaviour was investigated; the viscosity of Portland cement mortars with cement substitution by finely ground lamp glass waste powders obtained from incandescent light bulb borosilicate glass waste cullet and fluorescent lamp tube glass waste cullet was investigated by vibro-viscometer.

\section{Experimental study}

\subsection{Materials}

The constituent materials used in the laboratory to produce cement mortars comprised:

(i) Portland cement (PC) CEM I 42.5N with specific surface area (by Blaine) - $388 \mathrm{~m}^{2} / \mathrm{kg}$; soundness (by Le Chatelier) $1.0 \mathrm{~mm}$; setting time (initial/final) - 122/220 min; compressive strength (28 days) - $55 \mathrm{MPa}$; mineral composition (mass \%) $\mathrm{C}_{3} \mathrm{~S}-51.7, \mathrm{C}_{2} \mathrm{~S}-19.3, \mathrm{C}_{3} \mathrm{~A}-5.4, \mathrm{C}_{4} \mathrm{AF}-15.9$; density -3150 $\mathrm{kg} / \mathrm{m}^{3}$.

(ii) lamp glass waste powders (LGWPs) obtained from incandescent light bulb borosilicate glass waste cullet (LGWP1) and fluorescent lamp tube glass waste cullet (LGWP2) which were subjected to grinding using a planetary ball mill (Retsch PM 400, equipped with 4 steel jars of $500 \mathrm{ml}$ capacity each), operating at $300 \mathrm{~min}^{-1}$ rotation speed for 10, 20, 30, 40, 50 and 60 minutes. Hardened steel spheres of $17 \mathrm{~mm}$ diameter and $430 \mathrm{~g}$ mass per steel jar were used as grinding media. Specific surface area (by Blaine) is shown in Fig. 1.

(iii) chemical admixture Sikament 56 polycarboxylate superplasticizer admixture; appearance - light yellow turbid liquid, density - $1080 \pm 20 \mathrm{~kg} / \mathrm{m}^{3} ; \mathrm{pH}-4.5 \pm 1$; conductivity $2.14 \mathrm{mS} / \mathrm{cm}$; viscosity - easy flowing liquid; alkali content $\leq 0.8$ $\%$, chloride content $\leq 0.1 \%$.

(iv) water used within the mixtures was distilled water with $\mathrm{pH}-6.5$ and conductivity ranging between $10-20 \mu \mathrm{S} / \mathrm{cm}$.

The fineness of powders was obtained by a Blaine apparatus with $50 \mathrm{ml}$ cell volume (Bluhm \& Feuerherdt $\mathrm{GmbH}$ ) using a method with the prior need of measuring the density of the powder with a pycnometer in accordance with EN 196-6. The chemical analysis of powders was determined in conformity with EN 196-21 methodology and the results are summarized in Table 2.

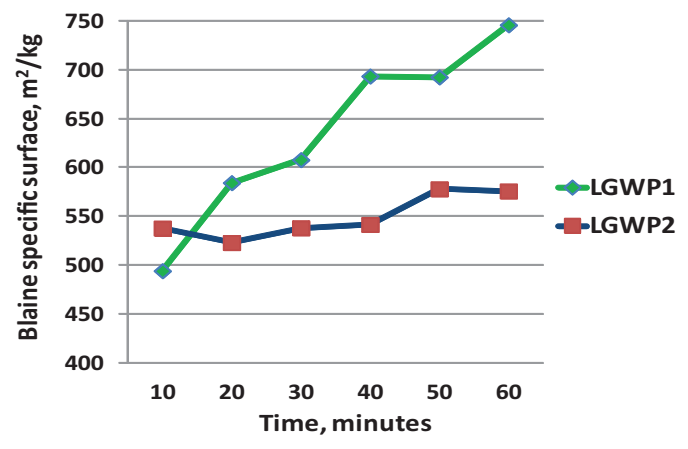

Fig. 1. The fineness of LGWP1 and LGWP2 powders vs. grinding time 1. ábra LGWP1 és LGWP2 hulladék üveg porok őrlési ideje és fajlagos felülete

\begin{tabular}{lcc} 
Blaine, $\mathrm{m}^{2} / \mathrm{kg}$ & \multicolumn{2}{c}{ Grindability, $\mathbf{k W} / \mathrm{Mt}$} \\
& Lamp glass & Portland cement \\
$\mathbf{3 5 0}$ & 41 & 45 \\
\hline $\mathbf{4 0 0}$ & 55 & 55 \\
\hline $\mathbf{5 0 0}$ & 80 & - \\
\hline $\mathbf{5 5 0}$ & 96 & - \\
\hline $\mathbf{6 0 0}$ & 112 & - \\
\hline
\end{tabular}

Table 1. Energy consumed in grinding the lamp glass according to [6] 1. táblázat Hulladék lámpa üvegek őrlésének energiaigénye [6]

\begin{tabular}{|c|c|c|c|}
\hline Bulk oxide, $\%$ by mass & LGWP1 & LGWP2 & PC \\
\hline $\mathrm{CaO}$ & 1.32 & 5.11 & 69.01 \\
\hline $\mathrm{Al}_{2} \mathrm{O}_{3}$ & 2.60 & 1.22 & 5.26 \\
\hline $\mathrm{SiO}_{2}$ & 71.14 & 65.52 & 18.74 \\
\hline $\mathrm{K}_{2} \mathrm{O}$ & 1.70 & 1.88 & 0.73 \\
\hline $\mathrm{Na}_{2} \mathrm{O}$ & 3.30 & 12.35 & 0.38 \\
\hline $\mathrm{Fe}_{2} \mathrm{O}_{3}$ & 0.17 & 0.11 & 2.03 \\
\hline Mno & 0.01 & 0.01 & 0.06 \\
\hline Mgo & 0.62 & 2.95 & 1.81 \\
\hline $\mathrm{TiO}_{2}$ & 0.01 & 0.03 & 0.26 \\
\hline $\mathrm{SO}_{3}$ & - & 0.14 & 3.00 \\
\hline $\mathbf{P}_{2} \mathbf{O}_{5}$ & 0.02 & 0.04 & 0.15 \\
\hline
\end{tabular}

Table 2. Chemical composition of lamp glass waste powders and Portland cement 2. táblázat A felhasznált hulladék üveg porok és cement kémiai összetétele

\subsection{Preparation of specimens}

Portland cement was substituted with LGWPs at a level of $30 \%$ by mass. The water to Portland cement ratio was selected to be $\mathrm{w} / \mathrm{c}=0.28$. Where Portland cement substitution by LGWP was applied, the apparent water to cement ratio was changed to $\mathrm{w} / \mathrm{c}=$ 0.37 (30\% LGWP), which, nevertheless, meant the same quantity of water respective to Portland cement content $(\mathrm{w} / \mathrm{c}=0.28)$. In total, 22 cement mortars were prepared. Six mortars designated D10, D20, D30, D40, D50 and D60 were prepared with cement substitution at a level of $30 \%$ with LGWP1 (grinding time from 10 to 60 minutes). Six mortars designated L10, L20, L30, L40, L50 and L60 were prepared with cement substitution at a level of $30 \%$ with LGWP2 (grinding time from 10 to 60 minutes). Three mortars designated Dp20, Dp40, Dp60 were prepared with cement substitution at a level of $30 \%$ with LGWP1 (grinding times 20, 40 and 60 minutes) and plasticizer at a dosage of $1 \%$ by weight of cement and $w / c=0.26$. Three mortars named Lp20, Lp40, Lp60 were prepared with cement substitution at level of $30 \%$ with LGWP2 (grinding times 20, 40 and 60 minutes) and plasticizer at a dosage of $1 \%$ by weight of cement and w/c=0.26. Two control cement mortars were prepared with superplasticizer admixture (termed PCp) and without superplasticizer admixture (termed PC). The components of the mortar mixture were batched by weight, PC and LGWP were premixed for 1 minute, then the entire amount of water was added gradually during a period of 2 minutes, followed by mixing for an additional 2 minutes and resulting in a total mixing time of 5 minutes. Mixing was carried out by a high shear benchtop mixer. 


\subsection{Viscosity test}

Rheological behaviour of cement mortars was tested after the mortar components were being mixed for 25 minutes, the time which corresponds to actual concrete placing terms [12].

Dynamic viscosity of cement mortars was tested by a sinewave vibro-viscometer SV-10 (of $0.01 \mathrm{mPa} \cdot \mathrm{s}$ accuracy) at 30 $\mathrm{Hz}$ frequency in a $35 \mathrm{ml}$ container. The SV-10 viscometer (A\&D, Japan) has two thin sensor plates that are driven with electromagnetic force at the same frequency by vibrating at constant sine-wave vibration in reverse phase like a tuningfork. The electromagnetic drive controls the vibration of the sensor plates to maintain constant amplitude. The driving electric current which is an exciting force will be detected as the magnitude of viscosity produced between the sensor plates and the cement mortar (see Fig. 2). The coefficient of viscosity is obtained by the correlation between the driving electric current and the magnitude of viscosity.

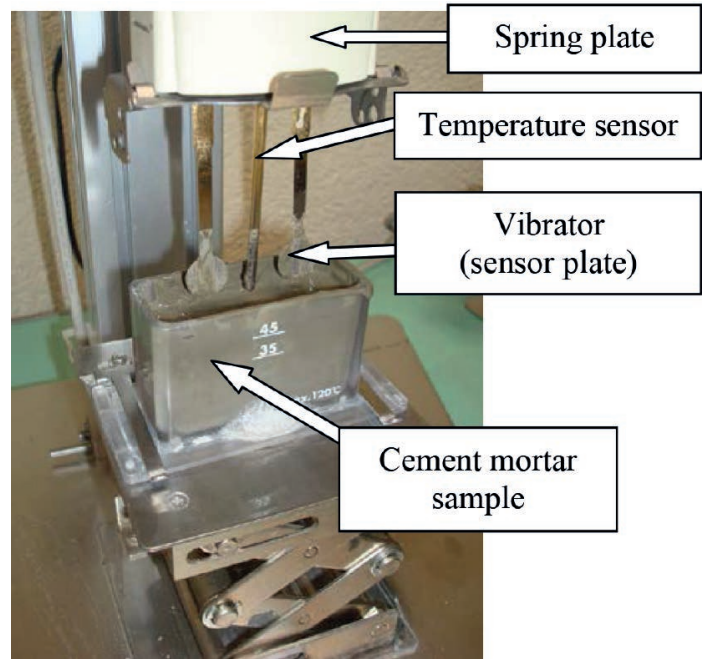

Fig. 2. SV-10 Vibro-viscometer with cement mortar sample 2. ábra SV-10 vibro-viszkoziméter cementpép mintával

\subsection{Electrical conductivity}

Electrical conductivity of cement mortars was studied immediately after mixing with water and at the 5th, 10th and 15th minute of the test with a Metter-Toledo MPC 227 device (electrical electrode in Lab 730, measuring interval: 0-1000 $\mu \mathrm{S} / \mathrm{cm}$ ). The measurements were obtained at an ambient air temperature of $21 \pm 0.5^{\circ} \mathrm{C}$.

\subsection{Compressive strength}

In order to determine the compressive strength of cement mortars with LGWPs, $40 \mathrm{~mm}$ cubic specimens were prepared. The utilization of glass waste in cement mortars requires certain grinding time and also energy consumption, as shown in Fig. 1 and Table 1, from which the optimal grinding time for lamp glass waste chips was chosen as 30 minutes in the present study. Portland cement was substituted at a level of $30 \%$ with LGWPs. Mortars were poured into steel moulds; the exposed surface of the specimens was covered with cling film to prevent moisture evaporation. Demoulding was carried out 24 hours after production and specimens were cured in water at a temperature of $20 \pm 2^{\circ} \mathrm{C}$ for 28 days. Compressive strength tests were conducted on an ALPHA 3-3000 S compression testing machine at the ages of 7,28 and 56 days.

\subsection{Ultrasound pulse velocity (UPV)}

In the early 1960's some researchers suggested using the ultrasonic transition time as a method for measuring the setting of mortars. In cooperation with the German dry mix company Hasit, Schleibinger Geräte $\mathrm{GmbH}$ developed a special data logger which controls up to 2 common ultrasonic pulse indicators, like the well-known Pundit 7, which was used in present study (Fig. 3). The measurements were carried out with fresh mortar being placed between two ultrasonic transducers, fed with 1 to 10 pulses per second at a frequency of $54 \mathrm{kHz}$. As setting progresses, the ultrasonic transition time through the mortar also changes. At the appearance of hydration product after the dormant period, the ultrasound pulse velocity sharply increases. At completion of the solidification process, however, the ultrasound pulse velocity will change little again. Researchers in [13] suggested that UPV can be used very effectively to monitor the hydration process and the formation of microstructure of cement mortars. Authors proposed to describe the hydration and hardening process in 3 steps: 1 - when UPV shows no change - at the beginning of hydrate formation (induction period, normally $(3-4$ h)); 2 UPV sharply increases - massive precipitation of hydrates with a progressive transition from amorphous to crystallized forms, the mixture stiffens (quick structure compaction period, until 24 h); 3 - UPV slowly increases and becomes stable, when the cement skeletons approach their final stiffness (slow structure compaction period, subsequent to $24 \mathrm{~h}$ ).
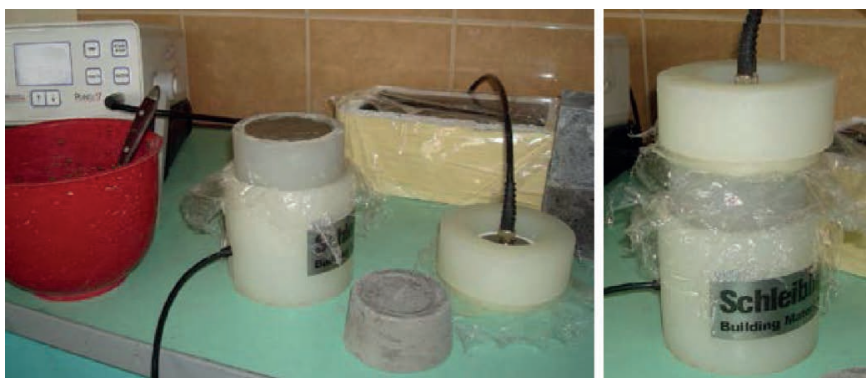

Fig. 3. Schleibinger Geräte GmbH Pundit 7

3. ábra Schleibinger Geräte GmbH Pundit 7 készülék

\section{Results and discussions}

\subsection{Viscosity}

The dependence of fineness of LGWP1 and LGWP2 powders on grinding time can be seen in Fig 1. There appears to be a considerable difference between the grindability of the two waste glass materials. Prolonged grinding has only a minor influence on the fineness of fluorescent lamp tube glass waste cullet, i.e. an increase up to $10 \%$, (LGWP2); whereas a more pronounced effect is noted in the case of incandescent light bulb borosilicate glass waste cullet (LGWP1), resulting in an increase in fineness by approximately 1.5 times more.

The time dependence of viscosity of cement mortars (w/ $c=0.28$ ) when the grinding time of LGWP2 was increased 


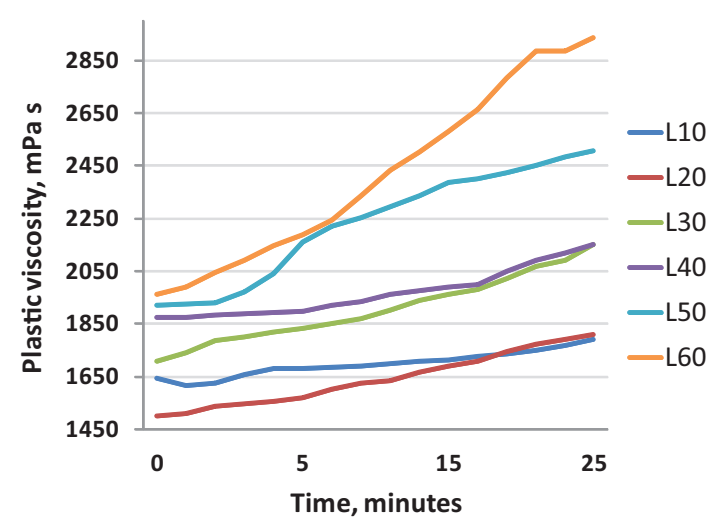

Fig. 4.a. Time dependence of viscosity of Portland cement mortar with the increase of LGWP2 waste glass powder grinding time without including PC results

4.a. ábra Viszkozitás és ôrlési idő összefüggése különböző mennyiségü LGWP2 hulladék üveg por adagolása esetén

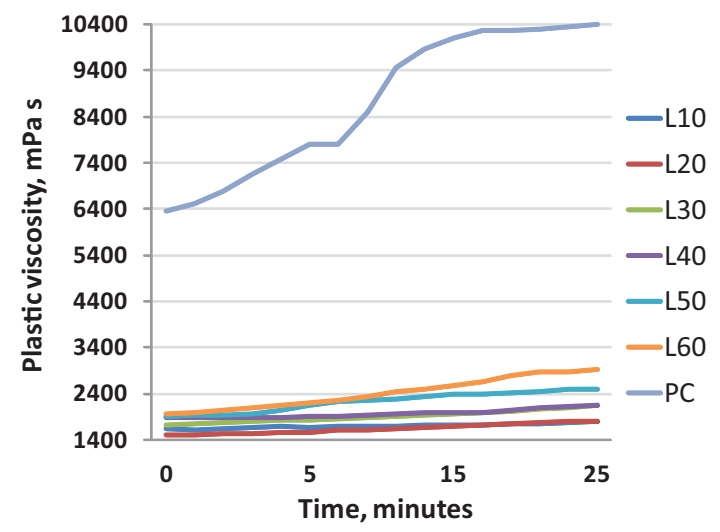

Fig. 4.b. Time dependence of viscosity of Portland cement mortar with the increase of LGWP2 waste glass powder grinding time with including PC results

4.b. ábra Viszkozitás és őrlési idő összefüggése különböző mennyiségü LGWP2 hulladék üveg por adagolása esetén; Portland cement pép eredményeivel összehasonlitva

from 10 to 60 minutes is shown in Fig. 4. This shows that an increase in grinding time of LGWP2 increases the viscosity of its cement mortar and, thus, adversely affects its rheological properties. The mortar L60 showed the highest viscosity due to its $10-15 \%$ higher specific surface area compared to mortar L10. It can be seen that the optimal grinding time for LGWP2 is 30 minutes.

The time dependence of viscosity of cement mortars when the grinding time of LGWP1 was increased from 10 to 60 minutes is shown in Fig. 5. It can be seen from Fig. 1 that LGWP1 is finer than LGWP2. The higher the grinding time of LGWP1, the lower is the viscosity of the cement mortar. Comparing Fig. 4 and Fig. 5, it is possible to conclude that the viscosity of cement mortars with LGWP1 is much higher than with LGWP2.

This can be explained by the fact that LGWP1 particles are finer and block the surface of the cement grains, therefore, the viscosity is higher in the mortars with larger grain sizes, meaning larger waste glass particles do not block the surface of cement grains. The finer particles are more active for pozzolanic reactions in the cement mortar. The best results from workability point of view were obtained in this series of experiment for the mortars D30, D40, D50 and D60, i.e. the viscosity of these mortars increased slower. In comparison

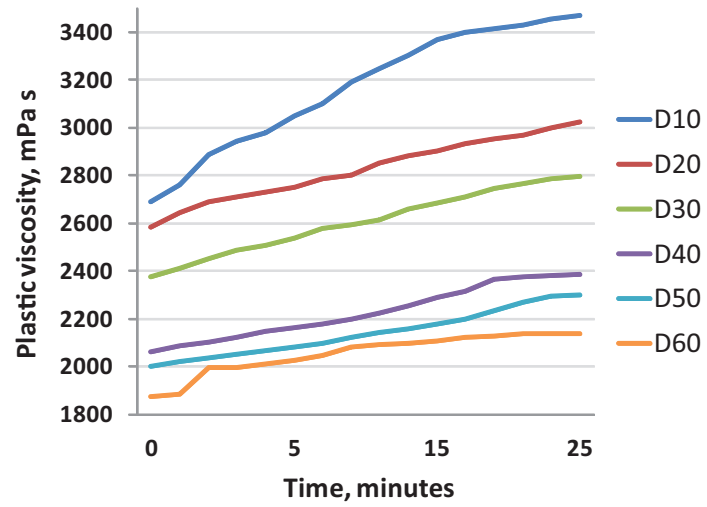

Fig. 5.a. Time dependence of viscosity of Portland cement mortar with the increase of $L G W P 1$ waste glass powder grinding time without including $P C$ results

5.a. ábra Viszkozitás és őrlési idő összefüggése különbözö mennyiségü LGWP1 hulladék üveg por adagolása esetén

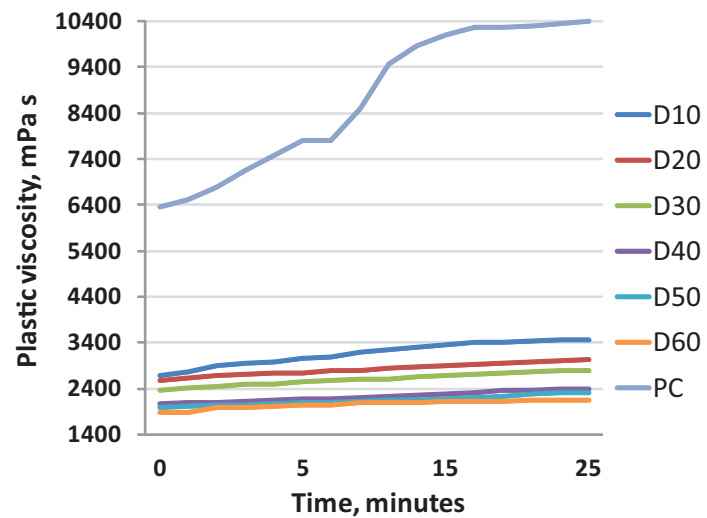

Fig. 5.b. Time dependence of viscosity of Portland cement mortar with the increase of $L G W P 1$ waste glass powder grinding time with including $P C$ results

5.b. ábra Viszkozitás és őrlési idő összefüggése különböző mennyiségü LGWP1 hulladék üveg por adagolása esetén; Portland cement pép eredményeivel összehasonlítva

with the control mortar, the cement mortar with LGWP1 also performed better. The optimal grinding time for LGWP1 appears to be between 30 and 60 minutes. In comparison to LGWP2 mortars, LGWP1 mortars have higher initial and final viscosity values. Moreover, the grinding time required to obtain the lower viscosity is 2-3 times higher than for LGWP2. It can also be seen that Portland cement substitution with LGWP1 and LGWP2 at a level of 30\% reasonably decreases the viscosity in comparison to the control mortar. The viscosity ranges from 1875 to $3475 \mathrm{mPa} \cdot \mathrm{s}$ with LGWP1, from 1500 to $3000 \mathrm{mPa} \cdot \mathrm{s}$ with LGWP2 and from 6500 to $10400 \mathrm{mPa} \cdot \mathrm{s}$ in the case of PC mortar.

The time dependence of viscosity of cement mortars with superplasticizer admixture $(\mathrm{w} / \mathrm{c}=0.26)$ when the grinding time of LGWP2 and LGWP1 was 20, 40 and 60 minutes is shown in Fig. 6. It can be seen that the addition of superplasticizer admixture into cement mortar reasonably lowered the viscosity of mortars with LGWP1 and LGWP2 powders and also changed their viscosity characteristics. The viscosity of Portland cement mortar with the addition of superplasticizer admixture decreased by 4 times on the $25^{\text {th }}$ mixing minute. It was observed that the LGWP2 mortars had higher viscosity than LGWP1 mortars and that let us to conclude that the finer LGWP1 powder without addition of superplasticizer 
admixture indeed blocks the surface of cement grains and reduces the plasticity of the mortar. It can also be seen that the viscosity of LGWP1 mortars with superplasticizer admixture ranged from 590 to $1600 \mathrm{mPa} \cdot \mathrm{s}$ that is $2-3$ times lower than for LGWP1 mortars without superplasticizer admixture. The viscosity of LGWP2 mortars with superplasticizer admixture ranged from 640 to $3150 \mathrm{mPa} \cdot \mathrm{s}$ and was mostly equal to the viscosity of LGWP2 mortars without superplasticizer admixture at longer grinding time of the powder. That indicates that present superplasticizer admixture Sikament 56 is not particularly suitable for the fluorescent lamp tube glass waste cullet powder LGWP2 and in order to reach the necessary effect in cement mortars, therefore, another superplasticizer admixture of lower $\mathrm{pH}$ and higher conductivity should be used for cement mortars with the fluorescent lamp tube glass waste cullet powder (LGWP2). The use of superplasticizer admixture carboxyment $3220 \mathrm{FM}(\mathrm{pH}-2.66$ and conductivity $-2.44 \mathrm{mS} / \mathrm{cm}$ ) for the cement mortar with fluorescent lamp tube glass waste cullet powder LGWP2 (termed LpS40) showed necessary effect (see Fig. 6).

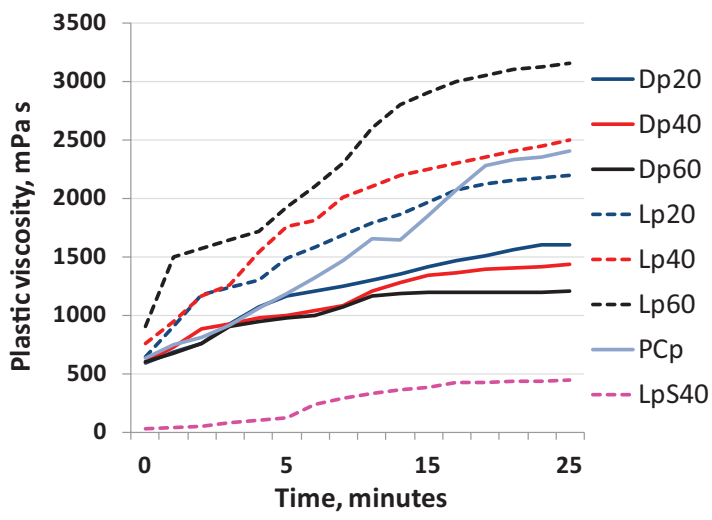

Fig. 6. Time dependence of viscosity of Portland cement mortar with plasticizer and LGWP1 and LGWP2 powders ground for 20, 40 and 60 minutes

16. ábra Viszkozitás időfüggése 20, 40 és 60 percig örölt LGWP1 és LGWP2 hulladék üveg por adagolása esetén Portland cement habarcsokban

\subsection{Electrical conductivity}

The electrical conductivity results are shown in Figs. 7, 8 and 9. It can be seen that the electrical conductivity for LGWP2 (Fig. 8) increases with the elapsed time of the experiment and with the fineness of the powder. The transition of cement mortar ions into the mortar strongly depends on time and increases the electrical conductivity in the mortars, with finer lamp glass powder particles this phenomenon is noticed only after 15 minutes.

In Fig. 7, it may be observed that LGWP1 mortars show the opposite tendency: electrical conductivity decreases when the grinding time increases. This could be attributed to the aggregation of glass particles and also to the fast reaction among the active components of LGWP1 (e.g. $\mathrm{Na}_{2} \mathrm{O}=3.30 \%$ which is 4 times less than in LGWP2, see Table 2) and hydrated cement minerals. Therefore, the electrical conductivity decreases in LGWP1 mortars with finer particles.

In Fig. 9, it can be observed that the addition of superplasticizer admixture into cement mortar changes the electrical conductivity characteristics of LGWP1 and LGWP2 mortars.
The common tendency is a decrease of the initial electrical conductivity values by 3-4 times, however, with increased fineness of the lamp glass waste powder, the electrical conductivity increases too. The LGWP1 mortars exhibit the already described tendency - with increased powder fineness the transition of cement mortar ions depends on time and an intensive maximum of electrical conductivity is noticed after 15 minutes. The LGWP1 mortars with superplasticizer admixture do not show such decrease in electrical conductivity with an increase in the fineness of the powder as observed in Fig. 7 in LGWP1 mortars without superplasticizer admixture.

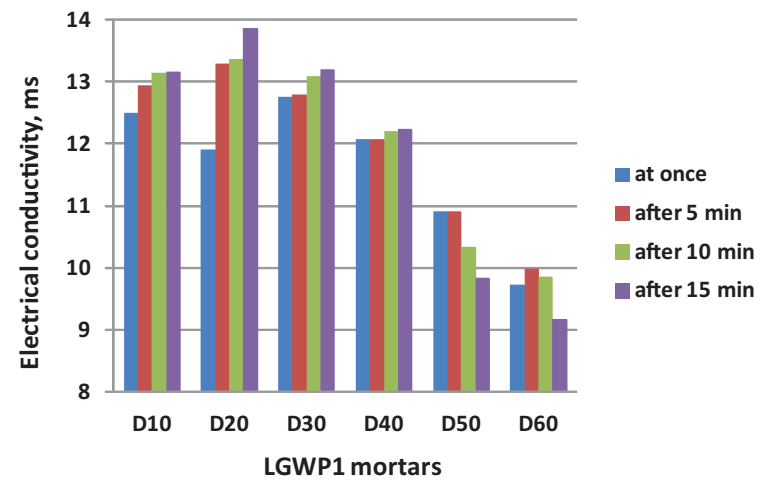

Fig. 7. LGWP1 electrical conductivity

7. ábra LGWP1 elektromos vezetőképesség

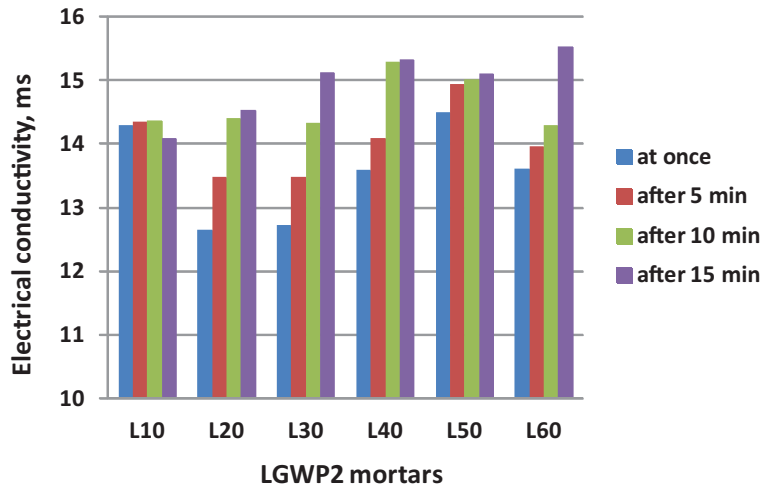

Fig. 8. LGWP2 electrical conductivity

8. ábra LGWP2 elektromos vezetőképesség

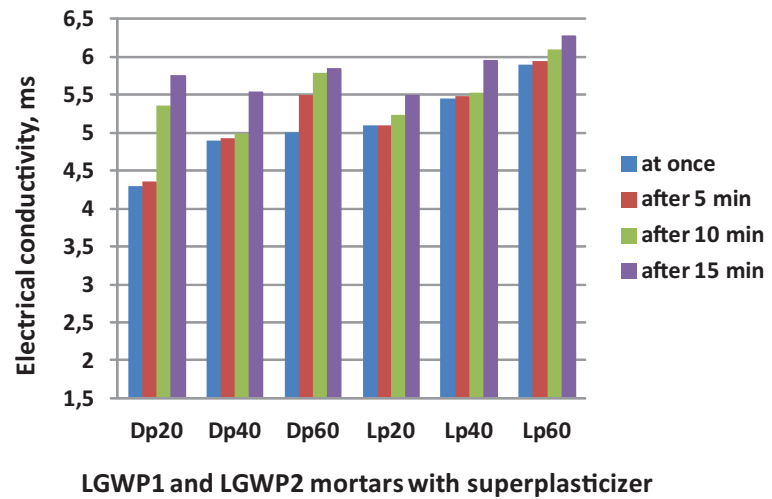

Fig. 9. Electrical conductivity of LGWP1 and LGWP2 mortars with superplasticizer admixture

9. ábra Folyósító adalékszerrel készült LGWP1 és LGWP2 habarcsok elektromos vezetőképessége 


\subsection{Compressive strength}

The size effect of ground glass on pozzolanic activity was observed in [6], the smaller the particle size the more reaction of the glass has with lime. This pozzolanic effect could be ascribed according to the Gurtin-Murdoch theory when the considerable surface to volume ratio in finely ground materials, the surface/interface effects, will alter the final effective mechanical properties. The compressive strength results are shown in Fig. 10. It can be seen that partial cement substitution with LGWP1 powder reasonably improved mechanical properties after 28 and 56 days; and substitution with LGWP2 powder slightly worsened the mechanical properties after 7, 28 and 56 days. Addition of superplasticizer admixture allowed decreasing the $\mathrm{w} / \mathrm{c}$ ratio and considerably improves the mechanical properties after 28 and 56 days. The compressive strength increase is about $15-17 \%$ for the mortar specimens with superplasticizer admixture. As can be seen, the best results were obtained for LGWP1 mortars with a maximum compressive strength for D30 amounting to $102 \mathrm{MPa}$ and Dp30 achieving $117 \mathrm{MPa}$ at the age of 56 days.

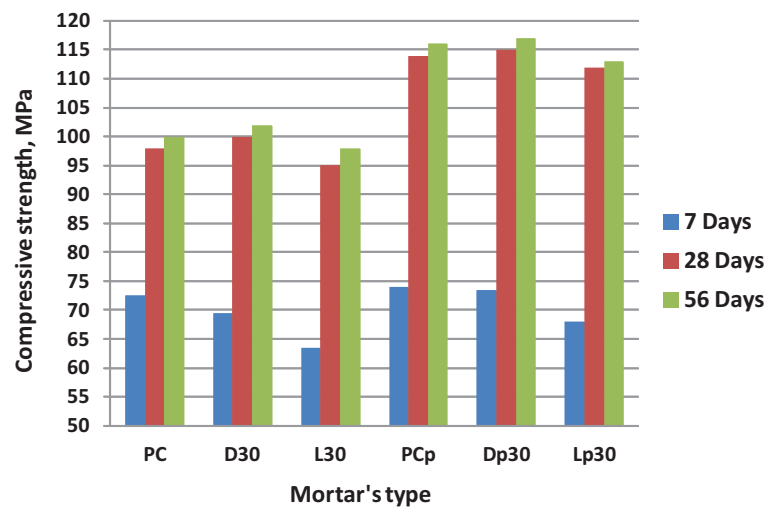

Fig. 10. Compressive strength of cement mortars with LGWPS 10. ábra LGWP habarcsok nyomószilárdsága

\subsection{Ultrasound pulse velocity (UPV)}

As shown in Fig. 11, the initial UPV values of LGPWs mortars are practically the same as for the reference mortar at about $900 \mathrm{~m} / \mathrm{s}$. The induction period within the first 4 hours, when the hydrate formation process was in progress, did not show any particular difference in UPV values. UPV sharply increased for all mortars within 4-14 hours of the induction period, and a slight difference ( 4-6\%) could be observed for the mortars with LGWPs in comparison to the reference mortar within 4-11 hours of the induction period. The UPV values for the D30 mortar were about 7-12\% lower within the period of 11-24 hours, with the final value being $11 \%$ lower at 24 hour than for the reference mortar. The difference in UPV values for L30 mortar were about 7-10\% lower within 11-24 hours, with the final value being $7 \%$ lower at 24 hour than for the reference mortar. The UPV values for the Dp30 mortar with superplasticizer admixture Sikament 56 were about $9-15 \%$ lower within the period of 8-16 hours, with the final value being $11 \%$ higher at 24 hour than for the reference mortar. The UPV values for the Lp30 mortar with superplasticizer admixture carboxyment 3220FM were about $12-20 \%$ higher within the period of 6-15 hours, with the final value being $10 \%$ higher at 24 hour than for the reference mortar.

The difference in UPV values for D30/L30 mortars (when Portland cement was substituted at the level of $30 \%$ by $15 \%$ of D30 and L30 powders each) was about 10-14\% lower within 11-17 hours, with the final value being $5 \%$ lower at 24 hours of the induction period in comparison to the reference mortar. Such impact of LGWPs can be attributed to their chemical properties and fineness. As a general observation, in the case of finer LGWPs particles, all additives shorten the duration of the induction period and accelerate the compaction of the structure during the early and medium term of hydration (up to $24 \mathrm{~h}$ ).

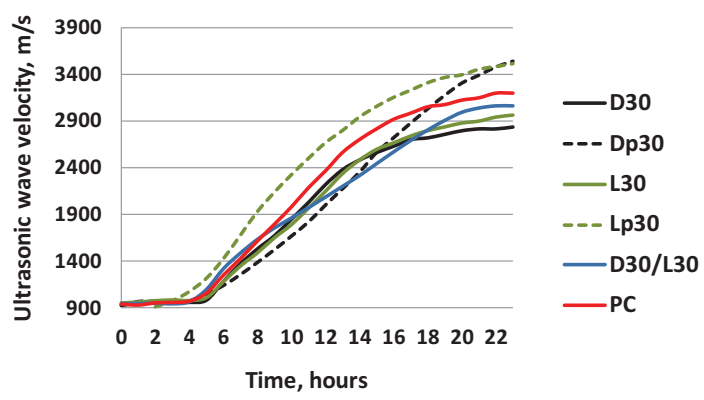

Fig. 11. Variation of UPV in reference mortar and mortars with LGWPS 11. ábra Ultrahang terjedési sebesség LGWP és referencia habarcsokban

\section{Conclusions}

The present paper has summarised the experimental results of a laboratory test series carried out on cement mortar specimens, in which two different lamp glass waste powders were used as cement component: i) incandescent light bulb borosilicate glass waste cullet powder (LGWP1) and ii) fluorescent lamp tube glass waste cullet powder (LGWP2). CEM I 42.5 N Portland cement was used with LGWPs powder substitution at a level of $30 \%$ by mass of cement.

It was demonstrated that:

- Rheological behaviour of cement mortar is improved by the application of lamp glass waste powders. However, the effectiveness of grinding time of lamp glass waste on the rheological behaviour and strength performance depends on the chemical composition of the glass waste used as a cement component in the cement mortars.

- The duration of grinding of fluorescent lamp tube glass waste cullet (LGWP2) has little influence on the fineness of the obtained powder whilst the fineness of incandescent light bulb borosilicate glass waste cullet powder (LGWP1) increases by approximately 1.5 times.

- The finer the incandescent light bulb borosilicate glass waste cullet powder (LGWP1) particles were, the lower viscosity and electrical conductivity were observed in the mortars.

- The finer the fluorescent lamp tube glass waste cullet powder (LGWP2) particles were, the higher viscosity and electrical conductivity were observed in the mortars.

- Addition of Sikament 56 superplasticizer admixture allowed a decrease in the viscosity by $2-3$ times in the cement mortars with the incandescent light bulb borosilicate glass waste cullet powder (LGWP1), but showed the necessity 
of using another superplasticizer admixture of lower $\mathrm{pH}$ and higher conductivity for cement mortars with the fluorescent lamp tube glass waste cullet powder (LGWP2).

- Addition of superplasticizer admixture allowed for a 3-4 times decrease in electrical conductivity in mortars.

- Portland cement substitution with lamp glass waste powders at a level of $30 \%$ is possible without any strength loss, moreover, the addition of superplasticizer admixture led to an increase in compressive strength by $15-17 \%$ in comparison to the control mortars.

- The use of finer LGWP particles shortened the duration of the induction period and accelerated the compacting of the structure during the early and medium term of hydration (up to $24 \mathrm{~h}$ ).

\section{Acknowledgement}

The author gratefully acknowledges the help of the VGTU Civil Engineering Centre and Scientific Institute of Thermal Insulation in providing the laboratory equipment and thankful to Dr. Ina Pundiene (VGTU) for discussions.

\section{References}

[1] Naik, T. R. (2011): Current sustainability issues and innovations in cementbased materials, Proceedings of $2^{\text {nd }}$ Workshop on The new boundaries of structural concrete, UPM \&ACI Italy chapter, Ancona, 2011, pp. 217-225.

[2] Corinaldesi, V. - Gnappi, G. - Moriconi, G. - Montenero, A. (2005): Reuse of ground waste glass as aggregate for mortars, Waste Management, Vol. 25, No. 2, pp. 197-201. http://dx.doi.org/10.1016/j.wasman.2004.12.009

[3] Caijun, S. - Zheng, K. (2007): A review on the use of waste glasses in the production of cement and concrete, Resources, Conservation and Recycling, Vol. 52, No. 2, pp. 234-247.

http://dx.doi.org/10.1016/j.resconrec.2007.01.013

[4] Andreola, F. - Barbieri, L. - Lancellotti, I. (2010): End of life-materials: WEEE glass recovery in construction sector, Proceedings of the second international conference on sustainable construction materials and technologies, Ancona. http://www.claisse.info/2010\%20papers/143.pdf

[5] Morais, A. S. C. - Caldas, T. C. C. - Monteiro, S. N. - Vieira, C. M. F. (2012): Characterization of fluorescent lamp glass waste powders, Materials Science Forum, Vol. 727-728, pp.1579-1584. http://dx.doi.org/10.4028/www.scientific.net/MSF.727-728.1579

[6] Shao, Y. - Lehoux, P. (2001): Feasibility of Using Ground Waste Glass as a Cementitious Material, Proceedings of the International Symposium: Recycling and reuse of Glass Cullet, Dundee, Scotland, pp. 209-219.

[7] Kara, P. (2014): Recycling of glass wastes in Latvia - Its application as cement substitute in self-compacting concrete, Journal of Sustainable Architecture and Civil Engineering, 2014, Vol. 1, No. 6, pp. 42-49. http://dx.doi.org/10.5755/j01.sace.6.1.6127
[8] Topcu, I. B. - Canbaz, M. (2004): Properties of concrete containing waste glass, Cement and Concrete Research, Vol. 34, No. 2, pp. 267-274. http://dx.doi.org/10.1016/j.cemconres.2003.07.003

[9] Metwally, I. M. (2007): Investigations on the performance of concrete made with blended finely milled waste glass, Advances in Structural Engineering, Vol. 10, No. 1, pp. 47-53. http://dx.doi.org/10.1260/136943307780150823

[10] Shakhmenko, G. - Korjakins, A. - Bumanis, G. (2009): Bore-Silicate Glass Waste of Lamp as a Micro-Filler for Concrete, Construction Science. Vol. 10, pp.131-138.

[11] Korjakins, A. - Shakhmenko, G. - Bumanis, G. (2012): Utilisation of Borosilicate Glass Waste as a Micro-Filler for Concrete, Journal of Civil Engineering and Architecture, Vol. 6, No. 7, pp. 876-883.

[12] Nagrockiene, D. - Pundiene, I. - Kicaite, A. (2013): The effect of cement type and plasticizer addition on concrete properties, Construction and Building Materials, Vol. 45, pp. 324-331.

http://dx.doi.org/10.1016/j.conbuildmat.2013.03.076

[13] Parr, C. - Lievin, M. - Wohrmeyer, C. - Alt, C. (2007): Optimization of the Hardening Properties of Refractory Castables Using Nondestructive Techniques to Measure Early Age Properties, International Journal of Applied Ceramic Technology, Vol. 4, No. 6, pp. 524 - 534.

http://dx.doi.org/10.1111/j.1744-7402.2007.02171.x

$\underline{\text { Ref.: }}$

Kara, Patricia: Performance of lamp glass waste powder (LGWP) as supplementary cementitious material (SCM) - viscosity and electrical conductivity

Építőanyag - Journal of Silicate Based and Composite Materials, Vol. 67, No. 1 (2015), 12-18. p.

http://dx.doi.org/10.14382/epitoanyag-jsbcm.2015.3

\section{Hulladék üveg por (WGP) cement kiegészítő anyag} (SCM) teljesítőképessége - Viszkozitás és elektromos vezetőképesség

Összefoglaló: A friss habarcsok reológiai tulajdonságai kulcsfontosságúak a bedolgozhatóság szempontjából (tömöríthetôség, szétosztályozódási hajlam stb.) és hatást gyakorolnak a megszilárdult állapotban mérhetô szilárdsági jellemzốkre. Hulladék üveg por alkalmazása cement kiegészitố anyagként jelentôs hatást gyakorol mind a bedolgozhatóságra, mind a szilárdságra. A cikk különbözô ôrlési idôtartammal (10-60 s) elôállított hulladék üveg porok hatását vizsgálja cement pépekben. Az optimális ốrlési időtartam meghatározása során az őrlés energiaigénye és a kialakuló fizikai, mechanikai jellemzốk optimalizálásával történik meg. Viszkozitás, elektromos vezetôképesség, ultrahang terjedési sebesség és nyomószilárdság vizsgálati eredmények kerülnek bemutatásra, a cement hulladék üveg porokkal történố 30\%-os helyettesítése mellett. Az eredmények rávilágítanak, hogy a vizsgált jellemzôkre a különbözô összetételú hulladék üveg porok más hatást gyakorolnak. Kulcsszavak: újrahasznosítás, viszkozitás, elektromos vezetôképesség, hulladék üveg, szemcseméret

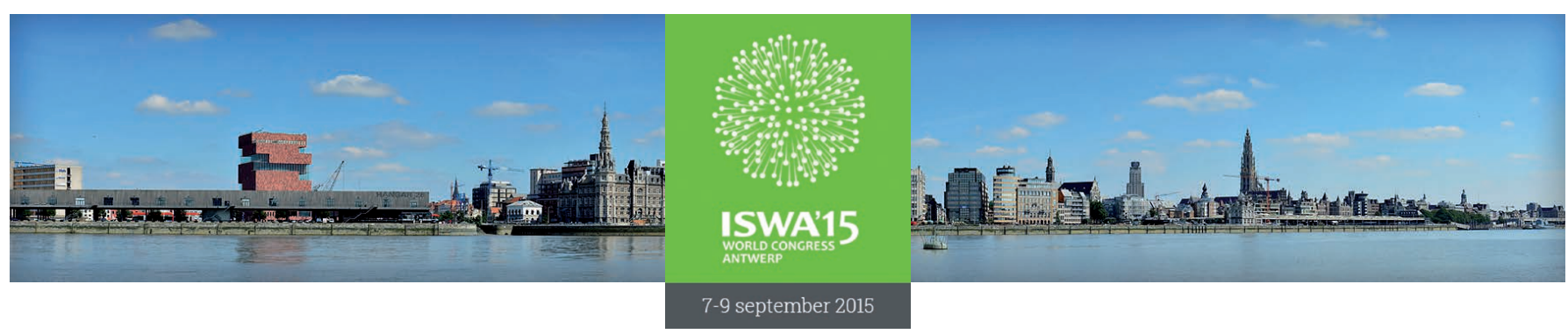

iswa2015.org - We aim to make this congress in Antwerp a memorable success. ISWA 2015 Antwerp will guarantee a balanced mix of internationally renowned keynote speakers, representatives of institutions and agencies worldwide that determine waste and materials policy, interesting insights into the latest scientific and technological developments in the sector, and above all, a lot of opportunities for networking and exchange of experience. 